\title{
The past as a lived space: heritage places, re-emergent aesthetics, and hopeful practices in NW Argentina
}

Marisa Lazzari ${ }^{1}$

María Alejandra Korstanje ${ }^{2}$

\author{
Journal of Social Archaeology 13 (3): 1-26 \\ Final and full version available at. \\ http://jsa.sagepub.com/content/13/3/394.abstract?rss=1
}

\section{Abstract}

This article explores the past as a lived, inhabited reality through a series of examples of indigenous heritage practices in NW Argentina (NWA), a region that in recent decades has seen increasing indigenous demands for autonomy as well as for land and cultural rights. This article seeks to understand the locations where heritage struggles emerge, as well as the artefacts around which they emerge, as social, semantic, and physical spaces of ontological multiplicity. Understanding how such places and artefacts are constituted as lived-in-the-flesh realities today requires examination of the multiple present connections that make them possible, as well as inquiry into how the sedimentation of previous lived experiences contributes to present understandings. This article examines ancient places that become gravity points, fuelling both indigenous politics and an academic practice with its own aesthetic code. To varying degrees, the cases explored reflect our involvement -- as archaeological researchers, professional advisors, and museum visitors -- with reemergent indigenous heritage practices in the region.

\section{Key words}

Archaeology, heritage practices, indigenous re-emergence, past-present, reemergent aesthetics

\footnotetext{
${ }^{1}$ Department of Archaeology, University of Exeter

${ }^{2}$ Instituto de Arqueología y Museo, Universidad Nacional de Tucumán; ISES- CONICET, Argentina
} 


\section{Introduction}

This article explores the past as a lived, inhabited reality through a series of examples of indigenous heritage practices in NW Argentina (NWA), a region that in recent decades has seen increasing indigenous demands for political autonomy as well as land and cultural rights. ${ }^{1}$ Centuries of colonial control and the violent military campaigns and assimilation policies of the $19^{\text {th }}$ and early $20^{\text {th }}$ centuries undoubtedly led to enormous losses across Argentina (in populations, native languages, and territories), yet native peoples have managed to weave a broad range of regional and local identities over time. In this context, re-emergence refers to the process of indigenous historical consciousness breaking into the public domain, to disrupt the homogenising discursive myths of Argentina's national identity that favours "gauchos" and "criollos" (Bartolomé 2004). This is not a minor achievement, given the degree to which the public sphere has increasingly become dominated by abrasive ideologies that undermine indigenous efforts. The voices that question the authenticity of this re-surfacing assume that indigenous claims are dangerous to the nation, and often use the region's rich historic and prehistoric data on migrations and cultural mixings against the country's own native population. A trap is therefore created, since in order to make claims, indigenous communities must engage with a range of interlocutors who may only listen if their expectations of what "ethnic" might mean are satisfied.

Several authors have examined how archaeological knowledge contributes to such abrasive ideologies in this particular Argentinean context (e.g., Curtoni 2009; Delfino and Rodríguez 1989; Quesada 2009; Taboada in press), and these works are in alignment with others that have observed the harmful logic imposed by frameworks 
that emphasize the modernist distinction between the past and the present across the world (Buchli and Lucas 2001; Colwell Chantaphohn and Ferguson 2008; Smith 2004). However, the path that is sometimes taken as an alternative to such views often promotes essentialised notions of specific, local identities, which ultimately implicitly deny the political agency of native peoples (Gallivan et al. 2011). Although we share these concerns, we insist that our efforts should be oriented towards integrating the past and the present on equal terms. While our knowledge of the past is always constituted from the present, the power that ancient artefacts and places have in framing current perceptions, understandings, and obligations between people, things, and places, needs to be acknowledged in its radical rawness. In this view, artefacts and places as/of heritage are not passive receptacles for today's discourses, but instead are constituent parts of "past-present systems", formations of lived social experience characterised by the mutual constitution of past and present realities (M. Lazzari 2011).

Understanding past-present systems requires the integration of archaeological knowledge and interdisciplinary analytical and interpretative techniques. Only then can we understand the locations where heritage struggles emerge (and the artefacts around which these may begin), as social, semantic, and physical spaces, where these systems become lived-in-the flesh realities (Castañeda 2010; Meskell 2005). This requires examination of the multiple present-day connections that make such systems possible, as well as inquiry into how the sedimentation of previous lived experiences contributes to present understandings. In other words, this is a sort of genealogy of ancestral practices, which finds both the continuities and the divergences meaningful. As such an aim exceeds the scope of the present article, we focus here instead on how particular ancient places become gravity points that fuel new types of indigenous politics and the academic practices around these with their own aesthetic code. To varying degrees, the cases explored reflect our involvement 
with emergent indigenous heritage practices in the region, as archaeological researchers, professional advisors, and museum visitors.

\section{Unstable boundaries}

The complexity and unpredictability of modes of subjectivization, identity, and affiliation, long studied in the social sciences and humanities (Bell 1999), become highly visible around heritage claims and cultural struggles for recognition, as affiliations can change quickly depending upon the political climates (Clifford 2004:23). The nuanced understandings of identity that circulate widely in academia fittingly describe such processes, yet they fail to capture the imagination of those involved in them. Identity politics has been described as the effect of the breakdown of grand historical and social narratives, revealing that subjectivity is fluid, shifting, and multi-positioned, while others have pointed out that such phenomena manifest the same old capitalist contradictions under a new idiom (see discussion in Butler, Laclau, and Zizeck 2000). At any rate, culture and identity are often experienced as enduring and transcendental by those claiming rights (Sahlins 1999). This is partly due to the fact that native claims usually confront a legal and political order that operates according to narrow definitions of ancestry, and which shapes political struggles into a battle of antagonistic categories based upon western dichotomies (Boccara and Bolados 2008; Povinelli 2002). Amidst this debate, is there any room for understandings of identity that embrace both essentialised self-definitions and a convoluted history and prehistory full of cultural exchanges and mixings? If so, it would be possible to understand the political agency of indigenous communities, on a worldwide basis, not as merely subordinate and "responding" to hegemonic orders, but also as a creative force, proposing new ways of understanding culture and society as dynamic processes. 
Argentina offers an interesting scenario for exploring these issues in depth, since discriminatory discourses have been established along the lines of being or not being "white", even though the definition of "whiteness" is quite a complicated matter in view of the long history of migrations and mixings that have shaped the nation. This logic permeates field encounters in situations marked by heritage struggles, depending on the fluctuating status of collaborations: "we" (academics, urban dwellers, non-rural residents, etc.) are categorised by "them" as "the white ones", just as "we" categorise "them" as indigenous or peasants (although they may often prefer to refer to themselves in many other ways, such as "indio", "originario", "comunero", "no-indio", etc.). These mutual classifications tend to flow along a continuum, where visible markers are indicative of the level of alignment between goals perceived to be different (García Azcárate and Korstanje in press).

Social imaginaries, the ways in which people imagine themselves to be, feed upon cultural products that are deemed to embody the inalienable, and later become cultural products themselves, circulating as currency (the "us"), and steering people into action (Taylor 2004). In the context of contemporary NW Argentina in particular, there is currently a battle between social imaginaries, as collective forms of indigenous identity have increasingly become explicit in the public sphere. While indigenous political activism has a long history in the region, these processes have recently achieved heightened visibility through the strength and resourcefulness of the claims presented. At the same time, these so-called re-emergent indigenous identities are construed by those who may have competing economic and/or cultural interests as a threat to the region and to the nation. Those supporting such views often seek evidence of the inauthenticity of new indigenous claims in the complex mixings and migrations that have characterised the region's colonial and postcolonial histories. This same 'evidence' therefore becomes a source of anxiety for 
those seeking recognition (Escolar et al. 2010; Lanusse and Lazzari 2005; A. Lazzari 2012). As a consequence, the long-term prehistory of the region, which is also characterised by population mobility and exchanges, can be seen as problematic if not downright dismissible by those seeking indigenous recognition. In this context, we often find that archaeologists in Argentina react by disconnecting contemporary indigenous communities from this deeper past, either by arguing for an absence of "true" continuity between the past and present, or by accepting such disavowal as part of a package related to how to "deal with the present". There is indeed a retreat from theoretical analysis, as if this situation is something that archaeologists have to contend with, but cannot interpret.

Nevertheless, the landscapes of NWA offer sufficient elements to allow theory to grow organically, since its long-term record of cultural fluidity makes nonessentialised readings of identity a necessity. In general, the region's archaeology reveals an openness to the mixing of materials and motifs in the design and manufacture of artefacts, since the earliest sedentary occupations (Lazzari 2005; Scattolin 2006). This is not surprising given the predominance of circulation practices (complex exchanges of people, animals, and goods) that took place at a variety of scales and across the entire sequence of human occupation. The ancient roads established by the seasonal movements of early hunter-gatherers were reused and extended throughout the changing socio-political orders that characterised later periods (Aschero 2007; Korstanje 2007). Later, both the Incas and the Spanish relocated people on a massive scale across the region as part of their strategies for domination (Rodríguez 2008a). However, mobility was more than just a dominance strategy, as native peoples drew upon circulatory strategies to avoid colonial obligations (Assadourian 1985), to pursue legal battles for claiming expropriated land, which demanded a presence at colonial high courts (Rodríguez 2011), and even to learn secret medicinal practices (Faberman 2005). This fluid, permeable, and 
constantly re-assembled life-world continues today, when native people travel and relocate for all sorts of reasons (Albeck et al. 2001), at times finding their indigenous activist voices quite far from their places of birth (Boullosa Joly 2006). It is this materiality -- a specific order of tangibility created by the mutuality of people, places, animals, and materials that embody multiple temporal scales -- which begs for a different approach to the understanding of the region's identities and communities today, as well as to political engagement.

\section{Identities as rhizomes}

Merleau Ponty (2002) understood existence as an inter-subjective field, and politics as a particular domain of such a field. As Coole (2001:270) has put it, these politics entail a "...kind of interpretative work [that]...begins with a feeling of one's times, their lacunae and possibilities", but they also "evaluate societies not in terms of their formal claims but on the basis of their lived relations." One such dimension of lived relations involves the interlinked nature of identity and materials. We would therefore like to explore this inter-subjective field of existence by drawing upon Latour's (1999) concept of networks of attachments: relationships with things that while partly related to individual/subjective experience (discursively acknowledged), are also manifestations of affects, pre-personal sensations that are only seen in the affected capacities of the interacting bodies. ${ }^{2}$ Affects are transformative, one becomes another through them, and their effects always transcend the subjectivities they traverse (Navaro Yahin 2009:12). This metaphor has the advantage of not only describing and allowing investigation of the constitution of identities, through constellations of bodies of various kinds and their relations, but also of enabling a different type of engagement with the self and others, as new assemblages unfold through the changing interventions of things in the lives of people. The ethical then 
involves material beings whose face also calls us into action. The political, not only 'the social', thus comes into being because of things (Bennet 2010; Lingis 1998).

The concept of networks thus defined allows the investigation of how action is allocated rhizomatically across various orders of beings. Latour (2011:798-99) has clarified his own model through the years, rejecting atomistic interpretations by explaining that networks are not just individual dots connected by lines, as they would be under a more conventional understanding. Networks are made of interconnected, inhabited spaces, themselves nothing more than the topographic aggregation of certain attributes, which in turn flow through the network in various states and degrees. The inside and outside are not relevant anymore as dimensions, given that "actants", of various kinds and themselves bundles of relations, are called upon to construct a particular version of the social. This "call" to create an assemblage, however, can be made by anybody along the flow, and in heritagemaking, the call is often placed by re-emergent objects: natural exposure of previously buried bones and artefacts, decaying sites, etc. Their needs are the ones that often set networks in motion; relationships acquire semantic depth because they are physical, and vice-versa. Conceiving of networks as fluid, inhabited spaces goes beyond their usual equivalence with "structure" (Knox et al. 2005). This makes it possible to think about space and relations without assuming limits or boundaries (e.g., the community, the region, the locality), and to follow connections to define the relevant spatial scale for the phenomena under analysis (in this case the reethnicised landscape) (Webmoor 2010).

As useful as this metaphor may be, in the formation of these networks the long duration becomes indistinct, with so much emphasis on the surface connections between co-existing phenomena. In heritage studies, it has been argued that Latour's networks still take objects and places as essentialised units, while in fact they are 
constituted through genealogies of discourses (Duineveld 2012). This is a necessary reminder that the reified "objects of heritage" result from contests of value in which positions and capacities to act are never equal (Meskell 2011; Weiss 2007). While the discursive dimension of the analysis includes a temporal dimension, a materialsbased perspective shows that, whatever "the social" might be, its ontology is made up of long-unravelling dialogues between substances, shapes, and practices that exceed discursive formations at any given time (Gosden 2008). Hodder (2012:105) has also called attention to the temporal dimension of human-thing entanglements, which he defines in a manner similar to Latour's assemblages, as empirically traceable "flows of matter, energy and information", although with an emphasis on human-material dependency rather than interaction. Humans are trapped in such entanglements because things are needed to create human life, but things also require maintenance and care in order for them to be relevant for allowing particular forms of sociality to unfold (Hodder 2012:88). These entanglements are partly residual in nature, developing through the existing material histories of which we are all a part, and which may move to the foreground in non-liner ways according to contingent relationships and events in the present (Hodder 2012:100-101).

'Things' then are rightly seen as gatherings of relationships (Brown 2001), but they are also objects in the sense of distinct entities that can sometimes propel human projects or else stand in their way. What we may understand as the material dimension of life exists as both "bounded entities" -- seemingly detached and selfcontained -- and as "peaks" in an open-ended relational space. These varying states of the material domain also have varying rules (expectations, strategies, modes of engagement). This shift between states of the material reveals that "materiality" and "identity" are analogous phenomena, as the process of identity-making oscillates between phases of detached and clearly delimited self-definition within a complex field of material and semantic relations that unfold in particular places over time. 
This dynamic process is particularly visible in the field of heritage struggles. Tangible forms materialise lingering memories and the actual physicality of things (and its demands) weighs heavily in the negotiation of the ways forward for these haunted spaces. This is a process that is perhaps better described through the image of geological breccias -- as jumbled amalgamations of different materials cemented together by a fine matrix -- rather than the more common metaphor of palimpsests (Bertolini 2012). However, in geology breccias are solidifications resulting from a catastrophe. While metaphoric parallels can be drawn for post-colonial contexts, it must be remembered that in such settings, loss is not a sedimented memory but a daily, bodily-felt relationship with a landscape that it is simultaneously owned, lost, and claimed. If past-present systems can be understood as breccias in constant formation, then paying attention to the long-term entanglement of people, materials, and places is central to an improved engagement with re-ethnicised landscapes.

\section{The powers of re-emergent assemblages}

One of the most notable places in NWA is the archaeological site known as the Ciudad Sagrada de Quilmes (the Sacred City of Quilmes) (Fig. 1, 2). This site is the region's finest example of the many large-scale fortified settlements that were built during the Late Period (1200-1436 AD) and inhabited throughout the Inca period and after the arrival of the Spanish. The Quilmes site belongs to the Comunidad India de Quilmes (CIQ), which has a vibrant and sometimes painful history that goes back centuries before the Spanish conquest. The memory of this history is often cited as one of the main justifications for a unified identity. The Quilmes territory is composed of loosely connected rural posts and locations, and unlike the nearby Amaicha indigenous community, they hold legal title to only a portion of their territory, which unfortunately does not include the sacred city itself (Fig.1). ${ }^{3}$ 
In the year 1630, the Quilmes population joined a large resistance confederation against the Spanish that lasted for several years. This confederation was loose and far from harmonious; but one of the things that called native people into action was, in addition to the Spanish occupation, the prospect of mining exploitation (Boixadós 2011), a significant parallel with today's anti-mining activism in the region. By 1665 the native population had been defeated and was facing dire consequences: indigenous leaders were brutally punished and large numbers of people were forcibly resettled 1500 kilometres away, in a coastal area near the city of Buenos Aires. These historical events fuelled the myth that most of the indigenous population had vanished from the region following the conquest. Yet while thousands were undoubtedly relocated, those who stayed were assimilated into the peasantry that provided the labour force for Spanish colonial haciendas (Rodríguez 2008a). Indigenous identity and heritage became a liability, and many disavowed these in order to meet the demands of the new socio-political environment. ${ }^{4}$ Despite this massive loss, native people managed to create regional identities over time, based on productive, communitarian, and cultural logics. Although the government of Argentina now recognises the community as a legitimate political interlocutor, the powerful and insidious work of continued questioning of the community's legitimacy becomes apparent in the social media and other outlets of expression. This symbolic violence also quickly becomes physical on the ground, as recent attempts at evictions from the Quilmes territory clearly show (Arenas 2011).

During the $20^{\text {th }}$ century, the Quilmes site suffered through many phases of research and poor management, including the loss of hundreds of valuable artefacts and a dubious excavation and reconstruction effort during Argentina's military dictatorship of the 1970's (Pierini 2011). In the 1990s, the site was leased to a private entrepreneur and artist to develop tourism operations, who reduced the size of the 
existing museum, and built a luxury hotel with a swimming pool on top of the site's cemetery (in an region where water is a scarce resource). This entrepreneur was eventually evicted by the provincial government because of his failure to make the required payments for the lease. In 2007, the Quilmes community decided to establish a picket line at the entrance to the site and initiate direct legal action to take the site back. Since 2008, the site has been under the community's custody, and site visits are now managed by them (Fig. 2$).^{5}$

In 2007 we co-organised a meeting along with local leaders and local cultural entrepreneurs, with the aim of opening up a approach to heritage issues in the area based upon dialogue. Although this meeting was held at the Quilmes community centre because of the available facilities there, it did not focus on their heritage specifically (García Azcárate et al. 2007). What emerged from that conversation was that there were common problems in relation to local heritage management, and that Quilmes was a case from which experience could be drawn in order to rethink future community heritage projects in the region. The concerns of the people involved not only the economic aspects of the site's use, but also its preservation, and there was a call for the site to be taken care of along with its surrounding land. Historical consciousness can follow many convoluted paths, but its emergence is often accelerated by the imperative call of material things with a deep temporal history. In this sense, Quilmes is itself an assemblage, a socio-material network of people, materials, and other beings, which are themselves constituted through these relationships. The site attracts people and prompts intervention, and the maintenance and conservation challenges stemming from its size (112 hectares) are impossible to ignore. Other agents intervene as well: domestic and wild animals whose presence seriously affects the site, natural processes of erosion and decay, legal policies that keep the site and community in a state of half-recognition, and police with rubber bullets periodically attempting to push people out of their houses in nearby localities. 
Last but not least, there are the antiguos, the ancient souls of the ancestors who still inhabit the site and dictate when and how the site must be approached and utilised (Boullosa Joly 2011; Becerra et al. 2012). The Quilmes assemblage is far from an essentialised totality, and closer inspection reveals that its boundaries are loosely defined, its constituent elements change frequently, and its political alliances fluctuate. What constitutes "Quilmes" can vary greatly: the boundaries of the claimed territory are well defined, but internal and external politics can greatly affect the community's collective composition.

This scenario is made more complex by the on-going confrontation between the community and the provincial authorities regarding ownership and administration of the Sacred City. A space for dialogue has been initiated (Mesa de Diálogo) in order to discuss the site's management and conservation, as well as the contents of the on-site museum. However, the meetings tend to reveal stark divisions between the negotiating parties. The Quilmes community wants to clearly link the site's past with their own present context of land and cultural struggles, through site activities and exhibitions that are rooted in their daily lives today. The government, on the other hand, wants a globalised aesthetic, and a narrative that erases conflict over land and resources from the exhibition. In the government's eyes, the story of Quilmes ended with the site's surrender to the Spanish. The strong relationship the community has with the site's present and past is judged to be re-invented (and inauthentic) fiction by the authorities, while at the same time they seek to package the site and Quilmes identity for tourism consumption, based upon international and urban standards that are certainly not common in the area. In the government's search for the exportable/saleable Quilmes, the narrative of the brave natives who resisted colonial invaders is central. However, today's descendants are cast as fakes who are trying to reap the benefits of a usurped historical relationship. The modern-day resistance of the Quilmes is ignored in official policy and quashed through repeated (though 
unpredictable) acts of direct violence. The government's position eventually feeds into the violent strategies of alleged landowners, who seek to push out individual families from contested land, while also creating internal rifts in the community regarding the appropriate strategies and leadership style necessary to meet these challenges. In the meantime, the Quilmes tourism guides walk the site with visitors, narrating its story through the weaving of historical facts, oral histories, and archaeological evidence, without concealing the complicated histories of population displacement. They know how to explain the site's past and present to the visitors, and one wonders why authorities do not take more time to listen to the Quilmes accounts.

Yet despite its gaps or inconsistencies, Quilmes -- the assemblage -- has also developed into a node within a landscape that reveals emergent "topographies of value" (M. Lazzari 2009): places that were alternately the centre and the periphery of research, but which are now key for accessing the area's history and resources. There is a wider process of indigenous political activism in the region, the "Unión Diaguita", ${ }^{6}$ a collective that loosely gathers various groups making claims for land and cultural recognition. The communities are not equally integrated within this collective, and many actually stay in the margins and even refuse to claim indigenous status. The spectrum of self-identification in the region is broad and convoluted, yet most people still experience the past as something that is present in many minute details of their daily lives. What is also common to many of these situations is the conflict between a known recent history of migrations and mixings, and an increasing demand to show "purity" when facing public and dominant discourses. This is perhaps partly manifested through the ambivalence towards archaeological sites, which are simultaneously seen as sources of ancestral power and places of danger and disease (Becerra et al. 2012; Karasik 2010). 
Some recent heritage practices, however, embrace the region's long-term history of mixing and recombination of both people and materials. For instance, within the same valley, about $60 \mathrm{~km}$ south of Quilmes (Fig. 1), there is a museum that has gained our attention due to its unprecedented dynamism and originality. ${ }^{7}$ The Museo Inti-Quilla ${ }^{8}$, in the community of Punta de Balasto, was created through the will and vision of a local resident who decided to exhibit his own collection in his house, without any kind of academic or government participation. The idea of the museum came after what the owner narrates as a miraculous encounter with an ancestor that he experienced while working in the fields as a child, but the actual collecting project started after a great upheaval caused by a mudslide (locally called a volcán) that buried most of the town. When the rains came and washed the ground, archaeological artefacts began to emerge, and called out to be assembled in a local collection. Since then, the owner's vision has become that of a museum that is run by his family, but conceived as an indigenous community museum. The museum does not charge for visits, accepting only voluntary contributions. In various informal interviews and conversations, the owner and his son have told us that they wanted a museum of everything, not just old pots, and of things that could be touched. Their museum is more interesting than others in the region, in their words, because it shows "things of the Indians, but also of the old people (e.g., their grandparents) and everything else".

This collection of artefacts involves all kinds of objects and materials, from typical archaeological artefacts to items that would not normally be included in that category (the pot his grandmother used for cooking; bank notes reflecting the various changes in the national currency). People from the local area and elsewhere started bringing donations, and the museum now has an interesting assemblage of diverse origins. Rare and highly valuable archaeological sculptures are not exhibited as being more important than other ordinary artefacts (such as old irons, everyday pots and pans), 
or even contemporary plastic objects. Many of the archaeological artefacts are also "intervened": they are painted, decorated, and incorporated into art projects (Fig. 3). These objects are equally valuable as "presenters" (in the sense of both introducers and facilitators of "presencing") of both the community's and the community members' life stages and relationships with the place. This is a museum of life in their community, understood as a network of relationships in space and in time.

This family is part of what has in recent years become the Comunidad Indígena Ingamana ${ }^{9}$, which is actively involved in demonstrations rejecting the open mining projects in the region. This re-emergence cannot be separated from Unión Diaguita activism and from Quilmes itself as a node, pulling in forces and radiating its influence beyond its boundaries -- so much so, that they have conducted reenactments of the Quilmes exodus in their own local public festivals (Fig. 4). The Ingamanas re-interpret the Quilmes and construct their own classifications, and in this process, a new assemblage reveals a reverse anthropology (Kirsch 2006), a theory of relational identity instantiated through artefacts. And here is where the rhizomatic model of identity can be limited if considered as contiguous relationships in space, but at the expense of time. As Weiner (1994) has argued, cultural difference is established via the density of inalienable things and places, a density that emerges from the connotations and associations (the metaphorical and metonymical layers) that are attached to things as a consequence of the long-term trajectories, transactions, and entanglements they experience.

At the Inti-Quilla museum, the juxtaposition of various kinds materials from the past and present reveals the haunting power that things from the past can possess. They make memories tangible, as well as the need for re-arranging these memories in specific ways, in order to make sense not only of the past, but also of the new presents and desired futures of particular localities. The museum is itself an 
assemblage, manifesting the past-present system that looks inwardly to the place where it is set and its deep-time history, but it also casts a wide network of explicit and non-explicit connections with co-existing socio-material orders, as well as those that previously existed. While the artefact displays emulate those of traditional museums in the invitation to visually read them, the accessibility of things and their arrangements imply alternative aesthetic values, which we call the aesthetics of reemergence.

\section{The aesthetics of re-emergence}

In its independence from official and professional discourses, as well as in its decidedly indigenous stance, the Inti-Quilla Museum forms a clear contrast with several other museums in the region. The complexity of community self-identification across the region has become visible through the myriad museums and heritage centres that have sprung up there during the last few decades. Many of these communities neither explicitly recognise themselves as indigenous, nor have they sought government recognition in that regard. However, the projects are all community-led developments mainly oriented towards maximising the economic and touristic potential of remote highland areas. In most cases, the decision-making process involves local families and archaeologists who work in the area (Aschero et al. 2009; Korstanje 2011; but see Korstanje and García Azcárate 2007).

One of us (Korstanje) is involved with the Museo Rural Comunitario in the El Bolsón Valley (Fig. 1), which started as a loosely conceived idea shared by archaeologists and local residents. In 2007 this idea became a reality following a collective community decision to build a museum. The actual design of the building was chosen by the town's mayor, following that of another community museum in a nearby 
locality that was designed by archaeologists. While this choice was certainly a surprising development for many involved in the project, an international grant enabled the collaborative task of deciding the museum's contents (Haedo et al. 2009), and opened new doors in terms of questioning the archaeologists' role in such processes and the expectations that both communities and archaeologists maintain (Korstanje et al. 2012). The process has indeed revealed the many ways in which popular aesthetics may be undermined, yet it has also shown how they can "return" at full force when the motivation for the exhibition project comes from the people themselves.

Museum aesthetics are indeed one of the key battlegrounds in heritage management efforts. The display of artefacts as texts that can be decoded visually (Classen and Howes 2006), as well as widely available conceptions of "museum aesthetics", such as those usually seen in association with UNESCO developments (Herzfeld 2010), become the de facto style of choice for museums, even community-oriented ones. We often find this to be the norm in NW Argentina, as the content of exhibitions tends to be produced by the communities, while the design of the exhibition (displays, colour schemes, sizes and numbers of artefacts displayed, modes of arrangement, media, etc.) is decided by museum experts based at national or provincial institutions. As in other parts of the world, local criteria for defining and organising what is being selected for exhibition are, at best, re-signified through stylised appropriations of motifs and media from local art forms, and at worst blatantly ignored (but see de Varine 2012; Holtorf 2011).

One of the main challenges faced in the museum project at El Bolsón was how to avoid the imposition of such codes. However, this refusal to impose was often met with resistance: researchers were often pushed to exercise their "aesthetic knowledge". One of the main problems with collaborative work emerges here as well: 
to what extent can we really comprehend the sensory and cognitive universe of the "other", particularly since this other is not a removed and romanticised community, but a loose assemblage of actors that fluidly includes and expels us through its very process of existence? Back in the 1970s Kusch (2002:68) examined the relationship with popular aesthetics in the Americas, particularly in terms of the rejection (repulsión) that anything "Americanist" caused among the elite and those of immigrant descent. With heightened sensorial language, Kusch wrote of the stench of the Americas (el hedor) as the bodily correlate of an underlying angst that sustained perfection at the expense of imperfection, an irritation caused by the absence of formal balance. The amorphous, as opposed to the finished, the complete, and the balanced, was rejected and feared, as if it was signalling the overturning of hegemonic power. This resonates with Bourdieu's (1998) analysis of working class aesthetics in France, which revealed how schemes of appreciation among working class people were those of life itself: form and function were not separated, and the aesthetic disposition was not separated from the practical one. "Popular" aesthetics were described as being based upon the continuity between art and life, and by the subordination of form to function. Yet the appreciation of form and materials can be decoupled from function in such settings. On many occasions we have found that rural residents of NW Argentina have built concrete walls at the front of their houses or around them, for no other reason than the joy produced by being surrounded by a different, "modern" material that sharply contrasts with the more common local ones such as stone and adobe. ${ }^{10}$ Clay, on the other hand, is mostly dedicated to making souvenirs for the tourists, some replicating traditional wares, others incorporating new motifs. Figure 5 shows an artefact made by a member of the family who owns the Inti-Quilla museum. Its maker told us that replicating anything in clay was a pleasurable activity, and that he did not make the figurines primarily to be sold. The artefact was given to us as a gift, as he wanted us to take it with us wherever we went. It could be easy to read this figurine as an 
aspirational modernity icon. A clay motorbike, however, also embodies a re-emergent life-world that finds joy in contradiction, and it shows how social sense and aesthetic sense are intimately connected.

This aesthetic sense was also apparent in El Bolsón during a community-organised trade fair, in which an archaeological artefact was curated and exhibited as heritage for the first time in the area (Fig. 6). The fair was called El Cambalacho, a term related to an old slang word for popular trade fairs where used goods are traded, and the term is also used more generally to refer to jumbled, mismatched things. The unexpected appearance of this artefact in this particular setting prompted consultants from Argentina's national agricultural agency (INTA) ${ }^{11}$ to comment on the "positive influence" that archaeological workshops and other outreach activities have had in the area. However, the display of this artefact signalled a greater departure: the exhibited pot, while valued as heritage, was also displayed as a vase holding flowers, and thus it was fully inserted into a new use-life context. ${ }^{12}$ The banner accompanying the pot showed a full biography for the artifact, including all previous known owners and its current status as somebody's personal property. This appreciation for things in their lived context became palpable when the content and design of the community museum exhibition had to be decided. The community initially expected that academics would make both the aesthetic choices and the choices related to content, leaving only the organisational logistics to them. When it became clear that this was not the case, a first moment of collective disorientation gave way to a blossoming of suggestions of colours, textures, objects, and overall layout that were seen as closer to their sentir --internal feelings (Korstanje et al. 2012). The resulting choices were very far removed from anything that would have been selected by archaeologists and other professionals, not only in terms of colours and display arrangement, but also in the terms used to name particular objects and the narratives that accompanied the items on display. 
The question is not one of deciding between "western" and "non-western" models of museum aesthetics, but one focused on how we can understand community-driven museum practices as existentially and politically meaningful. Museums are conceived as vaults, spaces removed from quotidian space where collecting is an expression of collective desire (Clifford 1988). If praxis has its own poesis (Gardiner 2000:80), community museums embody the contradictory situations and expectations of reemergent communities across the landscape: to find their own representational language when all languages have been extirpated, but also to partake in the elements and materials that will carry them forward. In this context, maintaining our version of "the local", even one that claims to be more attuned to the life-world of the people, is an imposition: our "horror" at seeing concrete walls in rural settings just another manifestation of the stench of popular aesthetics that Kusch denounced. Capturing the desires of the majority of a community is a utopian dream, not only because the collective desires behind museum projects do not have homogenous and clearly defined "communities of others" that support them (Waterton and Smith 2010), but also, because our desires are part and parcel of that fiction that we help to build through our practices.

\section{Concluding thoughts}

As in other parts of the world, the increasing expansion of new forms of land and resource exploitation in South America (for tourism, boutique wineries, opencast mining or biofuels) means that indigenous claims are at best seen as genuine but principally strategic in response to unfavourable political climates, or at worst, as a part of opportunistic strategies that capitalise on illegitimate connections with the past in order to reap the benefits of new forms of control over land and resources. This 
leads to seeing the past as either the primeval source of views and knowledge that may help to redress present-day disenfranchisement or as the "prey" for opportunistic individuals and groups. In both ways, the past is seen as passive and merely enacted in accordance to today's conflicts. As discussed above, we acknowledge the perils of objectified notions of the past in this context. However, we also question whether a focus on claims and discourses, at the expense of the longduration of configurations of materials, dilutes the past's haunting power, thereby creating consequences for the indigenous communities in the region that may be equally damaging.

One of the main problems we face as practitioners is the use of the region's rich history and prehistory against its own inhabitants, so much so that native collectives often have to turn away from their own historical capital in order to survive as a reinvented and crystallised community. Yet we have also observed a variety of practices that hint at a more nuanced understanding of the political agency of indigenous communities, one that sees such agency not as subordinate, merely responding to hegemonic orders, but also as a creative force that proposes new ways of understanding social life. This article has considered whether the answer may lie in looking at how social collectives emerge from within specific material orders, which have various levels of temporality embedded in them, just as much as they may emerge from present-day demands and pressures. The term materiality refers to the continuous, spiralling relationships of affirmation, opposition, care and obligation between people and the world of things, as these unfold over time in particular landscapes (M. Lazzari 2005). This is the context in which individual and collective existence and self-understanding acquire (or lose) sensibility, when past events and decisions -- even those long considered irrelevant or forgotten -suddenly gain a poignant relevance in the context of new political scenarios. A multiplicity of factors may lead to artefacts uncovered by a mudslide and collected 
without purpose becoming a museum; or to a poorly reconstructed and barely maintained archaeological site becoming a vortex of regional activism; or to an overlooked pot epitomising the biography of a community; or to a concrete wall being built to be admired or to prevent the destruction of homes in violent evictions; or to clay being shaped into mementos given as gifts. We have argued that while some of these entanglements are related to each other (Ingamanas and Quilmes), processes in other areas such as El Bolsón are comparable but partake of a different dialogue, and thus distinct approaches to community heritage have been produced. What unifies these cases is that they show that people can be relaxed when juxtaposing essentialised self-identifications and mixed-up pasts. Through various channels, such as exhibitions or narratives presented to site visitors, people pass on the lessons of the artefact domains that have surrounded them on the path to becoming who they are today.

In this context, what is the best methodology for developing collaborative projects, when all methodological decisions are mediated by our own aesthetic choices? Community museum practices in NW Argentina offer us an object lesson about what curating identity may mean. Such practices challenge our understandings of community, which typically stress spatial contiguity, order, coherence, and clusters of associated traits. While still straightjacketed by tourism markets, government regulations, global aesthetics, and urban notions of what "traditional" and "indigenous" may be, people are comfortable with jumbled material memories and non-consistent choices when building their own assemblages -- assemblages that may not necessarily have been initiated by human agency.

The future is the "third leg" of the triad that defines existential space (Jackson 2005). In response to the Quilmes community's requests for a collaborative, comprehensive heritage project involving their iconic site, we are currently developing a series of 
events geared towards creating relational objects or "tangible memories" (a collaborative site management plan, a photography exhibition, a mapping project, a conservation assessment, and an archival website) to signpost our future engagement. We learned from the curators at the Inti-Quilla museum that a heterogeneous collection of tools can be useful when being called into action.

\section{Acknowledgements}

We thank the people of Quilmes for welcoming us in their collaborative effort, and to the owners of the Museo Inti-Quilla for assisting with queries during various museum visits. Korstanje particularly thanks the people of El Bolsón Valley and her research team for all these years of sharing knowledge and friendship. Sean Goddard at the Drawing Office (Department of Archaeology, Exeter) provided technical assistance with the figures. This research was funded by an Arts and Humanities Research Council grant entitled "Identities as socio-material networks: perspectives from South America and beyond" (2010-12, http://identities.exeter.ac.uk/).

\section{Declaration of conflict of interest}

The authors declare that there is no conflict of interest

\section{References}

Albeck ME, Dipierri J, Alfaro E, Palomeque S (2001) La identidad de los casabindo a través del origen de sus apellidos. Actas XIII Congreso Nacional de Arqueología Argentina 1: 183-197. 
Arenas $\mathrm{P}$ (2011) Ni indígenas, ni aborígenes, ni originarios, ni preexistentes...

(primeros apuntes). In: Second international workshop Identities as socio-material networks. Past and present configuration in South America and beyond. University of Exeter, September 14-16.

Aschero CA (2007) Iconos, huancas y complejidad en la puna sur Argentina. In: Nielsen A, Rivolta M C, Seldes V, Vázquez M, Mercolli P (eds.) Producción y Circulación Prehispánicas de Bienes en el Sur Andino. Córdoba: Editorial Brujas, $135-66$.

Aschero CA, Arenas P, García Azcárate J, Ribotta E, Korstanje MA, Molinari R (1997) El presente del pasado: la propuesta de los amaicheños. Actas de las Jornadas de Antropología de la Cuenca del Plata, Vol. III. Rosario: Escuela de Antropología de Rosario, 68-73.

Aschero CA, Babot MdP, Cohen L, Hocsman S, López Campeny S, Martel A, Martínez J, Quiroga L, Romano A, Urquiza S (2009) Proyecto circuito turísticoarqueológico Punta de la Peña-Peñas Coloradas (Antofagasta de la Sierra, Catamarca, Argentina). In: Sepúlveda M, Briones L, Chacama J (eds.) Crónicas sobre la Piedra: Arte Rupestre en las Américas. Sociedad Chilena de Arqueología, Universidad de Tarapacá, 33-45.

Assadourian CS (1995) Exchange in the ethnic territories between 1530 and 1567. The visitas of Huánuco and Chucuito. In: Larson B and Harris O (eds.) Ethnicity, Markets and Migration in the Andes. Duke University Press, 101-34. 
Bartolomé M (2004) Los pobladores del 'desierto': genocidio, etnocidio y etnogénesis en la Argentina. Les Cahiers Amérique Latine Histoire et Mémoire 10 (consulted June 2012 http://alhim.revues.org/index103.html)

Becerra MF, Pierini MV, Rodríguez L, Sidy B, Tolosa S (2012) De ollitas y paredes volteadas a urnas y monumento patrimonial. La comunidad india de Quilmes y las resignificaciones del sitio arqueológico a partir de la reconstrucción. Nuevo Mundo Mundos Nuevos [Online], Section Current Issues (consulted 30 October http://nuevomundo.revues.org/64017)

Bartolini N (2012) Brecciation v palimpsest: understanding material and spatial jumbling in Rome. In: Association for Critical Heritage Studies inaugural conference, Gothenburg, June 4-8.

Bell V (1999) Performativity and belonging: an introduction. Theory, Culture \& Society $16(2): 1-10$

Bennet J (2010) Vibrant Matter. A Political Ecology of Things. Duke University Press.

Boccara G and Bolados P (2008) ¿Dominar a través de la participación? El neoindigenismo en el Chile de la posdictadura. Memoria Americana 16 (2):167-196.

Boixadós R (2011) Rebeldes, soldados y cautivos. Etnografía de un episodio en la Frontera de Guerra del valle Calchaquí (1634). In: Rodríguez L (comp.) Resistencias, Conflictos y Negociaciones. El Valle Calchaquí desde el Período Prehispánico hasta la Actualidad. Rosario: Prohistoria Ediciones, 93-122. 
Boullosa Joly M (2006) Re-Devenir Indien en Argentine - Amaicha et Quilmes à l'Aube du XXlème Siècle. PhD thesis, Ecole des Hautes Etudes en Sciences Sociales, Paris.

Boullosa Joly M (2011) El sitio arqueológico de Quilmes: de vestigios malditos a "ciudad sagrada". In: Second international workshop Identities as socio-material networks. Perspectives from South America and beyond. University of Exeter, September 14-16.

Bourdieu, P (1998) La Distinción. Criterios y Bases Sociales del Gusto. Madrid: Taurus.

Brown, B (2001) Thing theory. Critical Inquiry 28:1-22.

Buchli, V and G Lucas (2001) The absent present: archaeologies of the contemporary past. In: V Buchli and Lucas G (eds.). Archaeologies of the Contemporary Past. London: Routledge, 3-18.

Butler, J, Laclau E and Zizeck S (2000) Contingency, Hegemony, Universality: Contemporary Dialogues on the Left. London: Verso

Castañeda Q (2009) The 'past' as transcultural space: using ethnographic installation in the study of archaeology. Public Archaeology: Archaeological Ethnographies 8(23): 262-282

Classen C and D Howes (2006) The museum as sensescape: western sensibilities and indigenous artifacts. In: Edwards E. Gosden C and R. Phillips (eds.) Sensible Objects: Colonialism, Museums and Material Culture. Berg, 199-222. 
Clifford J (1988) The Predicament of Culture. Twentieth Century Ethnography, Literature and Art. Cambridge, MA: Harvard University Press.

Clifford J (2004) Looking several ways. anthropology and native heritage in Alaska. Current Anthropology 45 (1):5-30.

Colwell-Chanthaphonh C and Ferguson J (2008) Collaboration in Archaeological Practice. Engaging Descendant Communities. Lanham, MD: Altamira Press.

Coole D (2001) Thinking politically with Merleau Ponty. Radical Philosophy 108:1728.

Curtoni R (2009) Arqueología, paisaje, y pensamiento decolonial. Reflexiones para una diversidad epistémica. In: Berberena R, Borrazzo K, Borrero L (comp.), Perspectivas Actuales en Arqueología Argentina. Buenos Aires: IMHICIHU, 13-32.

Deleuze G and Guattari F (1987) [1980] A Thousand Plateaus. Capitalism and Schizophrenia 2. Minneapolis: University of Minnesota Press.

Delfino D and Rodríguez P (1989) Cuando los arqueólogos vienen marchando: Interrogantes y propuestas en torno a la defensa y el rescate del patrimonio arqueológico. Revista de Antropología 7 (10): 51-57.

De Varine H (2012) As Raízes do Futuro: O Patrimônio a Serviço do Desenvolvimento Local. Porto Alegre, Brasil: Editora Medianiz. 
Duineveld M (2012) The ontological politics of heritage practices. Towards a genealogical approach of object formation in heritage studies. In: Association for Critical Heritage Studies inaugural conference, Gothenburg, June 4-8.

Escolar D (2005) El 'estado del malestar.' Movimientos indígenas y procesos de desincorporación en la Argentina: el caso huarpe. In: Briones C. (ed.) Cartografías Argentinas. Políticas Indigenistas y Formaciones Provinciales de Alteridad. Buenos Aires: Antropofagia, 45-78.

Escolar D, Delrio W and Malvestitti M (2010) ‘Criminalización y distorsión de las demandas indígenas en Argentina. La construcción mediática del pueblo Mapuche como no-originario. Journal de la Société des Américanistes [Online] 96 (1) (consulted 01 July 2012, http://jsa.revues.org/index11404.html)

Faberman J (2005) Las Salamancas de Lorenza. Magia, Hechicería y Curanderismo en Tucumán Colonial. Buenos Aires: Siglo XXI.

Gallivan M, Moretti-Langholtz D, Woodward B (2011) Collaborative archaeology and strategic essentialism: native empowerment in Tidewater Virginia. Historical Archaeology 45 (1):10-23.

García Azcarate J and Korstanje MA (in press) ¿De las utopías de quiénes estamos hablando? Acerca de la gestión intercultural del patrimonio arqueológico con comunidades indígenas en el NOA. Nuevos Mundo, Mundos Nuevos

García Azcárate J, Gerónimo D, Korstanje MA, Lazzari M (2007) Quilmes: the story of the 17th century genocide, and the historical reparation that still fails to come. In: 
Symposium Cultural Heritage, Social Justice and Ethical Globalisation. Flinders University, Adelaide, Australia, September 28-29.

Gardiner M (2002) Critiques of Everyday Life. London: Routledge.

Gosden C (2008) Social ontologies. Philosophical Transactions of the Royal Society B 12, 363 (1499): 2003-10.

Haedo A, Korstanje MA, Maloberti M, Pigoni M, Zapatiel J, Quesada M (2009) La construcción de la memoria en un museo: ¿Cómo y quiénes participan de la misma? El ejemplo del Bolsón (Catamarca). Serie Monográfica y Didáctica 48:122. Universidad Nacional de Tucumán.

Herzfeld M (2010) Engagement, gentrification, and the neoliberal hijacking of History. Current Anthropology 51(Supplement 2): S259-S267.

Hodder I (2012) Entanglement: An Archaeology of the Relationships between Human and Things. John Wiley\& sons

Holtof C (2001) Places as Stories (consulted November 2011 http://Inu.se/research/research-database/project.aspx?id=1271\&l=en)

Isla A (2009) Los Usos Políticos de la Identidad. Criollos, Indígenas y Estado. Buenos Aires: Libros de la Araucaria. 
Jackson M (2005) Existential Anthropology: Events, Exigencies, and Effects.

Berghahn Books.

Karasik G (2010) Haciendas, campesinos y antropología: conflictos sociales y colonialidad en el extremo Noroeste Argentino en la Primera Mitad del Siglo XX. Travesía. Revista de Historia Económica y Social 9.

Kirsch S (2006) Reverse Anthropology: Indigenous Analysis of Social and Environmental Relations in New Guinea. Stanford University Press.

Knox H, Savage M, Harvey P (2005) Social networks and spatial relations: networks as method, metaphor and form. Centre for Research on Socio-Cultural Change (CRESC) Working Paper Series. The Open University, 1-24.

Korstanje MA (2007) Territorios campesinos: producción, circulación y consumo en los valles altos. In: Nielsen A, Rivolta MC, Seldes V, Vázquez M, Mercolli P (eds.) Producción y Circulación Prehispánicas de Bienes en el Sur Andino. Córdoba: Editorial Brujas, 135-66.

Korstanje MA (2011) Inquietudes y goces: negación y elogio de las estéticas populares. In: Second international workshop Identities as Socio-Material Networks: Past and Present Configuration in South America and Beyond. University of Exeter, September 14-16.

Korstanje MA and García Azcárate J (2007) The Qhapaq Ñan project: a critical sight. Archaeologies 3 (2):116-131. 
Korstanje MA, Quesada M, Haedo A (2012) El desafío de los museos comunitarios.

In: VI Reunión de Teoría Arqueológica de America del Sur, Goiana, Brasil, September 17-21.

Kusch R (2002) Anotaciones para una estética de lo Americano. El Perseguidor, Revista de Letras 10 (8): 67-70.

Lane K (2011) Between water and a hard place: heritage, technology, and campesinos in the north-central Andes of Peru. In: First international workshop Identidades como redes socio-materiales: perspectivas desde Sudamérica y más Allá. Horco Molle, Tucumán, Argentina, April 24-27.

Lanusse P and Lazzari A (2005) Salteñidad y pueblos indígenas: continuidad y cambio en identidades y moralidades. In Briones C. (ed.) Cartografías Argentinas: Políticas Indigenistas y Formaciones Provinciales de Alteridad. Buenos Aires: Antropofagia, 223-52.

Latour B (1999) Factures/fractures: from the concept of network to the concept of attachment. RES: Anthropology and Aesthetics 36: 20-31.

Latour B (2011) networks, societies, spheres: reflections of an actor-network theorist. International Journal of Communication 5: 796-810.

Lazzari A (2012) Emergence in re-emergent indians: para-history of the re-emergent rankülche indigenous people. Nuevo Mundo Mundos Nuevos [Online] (Consulted 30 October 2012 http://nuevomundo.revues.org/64024)

Lazzari M (2005) The texture of things: objects, people and landscape in NW 
Argentina (first millennium AD). In: Meskell L (ed.) Archaeologies of Materiality. Oxford: Blackwell, 126-61.

Lazzari M (2009) Topographies of value: ethical issues in landscape archaeology. In: David B and Thomas J (eds.) Handbook of Landscape Archaeology. Walnut Creek: Left Coast Press, 644-53.

Lazzari M (2011) Tangible interventions: the lived landscapes of contemporary archaeology. Journal of Material Culture 16 (2):171-192.

Lingis A (1998) The Imperative. Indiana University Press.

Lorandi A and R Boixadós (1987-88) Etnohistoria de los Valles Calchaquíes en los siglos XVI y XVII. Runa 17-18: 263-419.

Merleau Ponty M (2002) [1962] Phenomenology of Perception. An Introduction. Routledge.

Meskell L (2005) Archaeological ethnography. Conversations around Kruger National Park. Archaeologies 1 (1):81-100.

Meskell L (2011) The Nature of Heritage: The New South Africa. Wiley-Blackwell.

Navaro Yahin Y (2009) Affective spaces, melancholic objects: ruination and the production of anthropological knowledge. Journal of the Royal Anthropological Institute 15: 1-18. 
Pastor G and D Sánchez Fuentes (2009) Cruce de miradas. visibilidad e invisibilidad del paisaje en territorios sujetos a usos turísticos. Cuadernos de Investigación Urbanística 66: 67-82.

Pierini MV (2011) La comunidad india de Quilmes en la década de 1970. Reflexiones iniciales sobre la historia de su organización. In Rodríguez L (comp.) Resistencias, Conflictos y Negociaciones: el Valle Calchaquí desde el Período pre-Hispánico hasta la Actualidad. Buenos Aires: Ediciones Prohistoria, 197-210.

Povinelli E (2002) The Cunning of Recognition: Indigenous Alterities and the Making of Australian Multiculturalism. Durham, NC: Duke University Press.

Quesada M (2009) Discursos cartográficos y territorios indígenas en Antofalla. Intersecciones en Antropología 10:155-69.

Rodríguez L (2008a) Después de las Desnaturalizaciones. Transformaciones Socio-económicas y Etnicas al Sur del Valle Calchaquí. Santa María, Fines del Siglo XVII - XVIII. Buenos Aires: Antropofagia.

Rodríguez L (2008b) Los Ingamana en Andalgalá a principios del siglo XVIII. Notas sobre la memoria y la identidad. Andes 19:279-298.

Rodríguez L (2011) El viaje de Don Lorenzo y otros "peregrinajes". Reclamos territoriales, identidad y memoria en la Comunidad de Amaicha del Valle. In: Rodríguez, L. (comp.) Resistencias, Conflictos y Negociaciones: el Valle Calchaquí desde el Periodo pre-Hispánico hasta la Actualidad. Buenos Aires: Ediciones Prohistoria, 123-44. 
Sahlins, M (1999) Two or three things that I know about culture. Journal of the Royal Anthropological Institute 5 (3):399-421.

Scattolin MC (2006) Contornos y confines del universo iconográfico precalchaquí del valle de Santa María. Estudios Atacameños 32: 119-39.

Smith L (2004) Archaeological Theory and the Politics of Cultural Heritage. London: Routledge

Taboada C (in press) Reflexiones sobre arqueología y construcción de identidades para Santiago del Estero. In: Trabajo y Sociedad. Santiago del Estero (Argentina): Instituto de Estudios para el Desarrollo Social (INDES), Universidad Nacional de Santiago del Estero.

Taylor C (2004) Modern Social Imaginaries. Durham, NC: Duke University Press.

Weiner A (1994) Cultural difference and the density of objects. American Ethnologist 2 1(2):391-403.

Waterton $E$ and $L$ Smith (2010) The recognition and misrecognition of community heritage. International Journal of Heritage Studies 16 (1-2):4-10.

Weiss L (2007) Heritage Making and Political Identity. Journal of Social Archaeology 7 (3): 413-31.

Webmoore T (2010) What about 'one more turn after the social' in archaeological reasoning? Taking things seriously. World Archaeology 39 (4):563-78 


\title{
Notes
}

\begin{abstract}
${ }^{1}$ Legal changes to the national constitution in 1994 granted recognition of pre-existence to all indigenous people in the national territory. This reform was carried out (almost inadvertently and certainly regretted post facto) under the same government whose neo-liberal policies caused a catastrophic fall in the traditional supportive role of the provincial governments in rural communities. This fall of the provincial welfare state, as well as the advance of certain industries over fiscal territories with traditional occupation, accelerated the processes of indigenous self-identification and community organisation in the 1990s (Escolar 2005).
\end{abstract}

${ }^{2}$ The translator of Deleuze and Guattari (1987:xvi) offers the following definition: "Affect/Affectation: Neither word denotes a personal feeling (sentiment in Deleuze and Guattari). L'affect (Spinoza's affectus) is an ability to affect and be affected. It is a prepersonal intensity corresponding to the passage from one experiential state of the body to another and implying an augmentation or diminution in that body's capacity to act."

${ }^{3}$ Amaicha is the oldest recognised indigenous town in NW Argentina, holding a Royal Charter (Cédula Real) from the Spanish Crown dating to 1716. This right was secured in 1995 by the official and legal granting of the land title. The Royal Charter included Quilmes as well, however, these two communities' history of land right struggles diverged in the $19^{\text {th }}$ century when Quilmes land was sold to private owners while the Amaichas managed to keep continuous control over theirs (Isla 2009). An account of the earliest collaborative archaeological project in the region can be found in Aschero et al 1997.

${ }^{4}$ Characteristically, the native language (Kakan) was lost in this process, giving way first to Quechua as a lingua franca (Lorandi and Boixadós 1988) and then to Spanish.

${ }^{5}$ While there is wide recognition that the site and its care are in the community's hands, this possession has not yet been legally recognised. There is a legal action pending against the community for unlawful take-over of the site and premises, therefore they have not been able to access the museum and open it to visitors.

${ }^{6}$ Diaguita was the name given to the inhabitants of the region by Spanish authorities during colonial times.

${ }^{7}$ It should be noted that the following observations stem from repeated visits during our archaeological and heritage fieldwork activities in the area, and not from systematic research.

${ }^{8}$ Inti-Quilla means "sun moon" in the Quechua language, and these are two of the most powerful deities of ancient times, generally related to the Inca.

${ }^{9}$ Ingamana was the name of the indigenous people who were in the area at the time of the Spanish arrival (Rodríguez 2008b).

${ }^{10}$ This is particularly noticeable in areas where the tourist industry is booming, see Pastor and Sánchez Fuentes (2009). Lane (2011) has also discussed the preference for concrete as a building material in rural areas in Peru. It should be noted that at Quilmes, concrete is often the material of choice when building houses that can withstand the violent eviction attempts that they periodically face.

${ }^{11}$ INTA stands for Instituto Nacional de Tecnología Agropecuaria (Argentina's national agency for supporting agricultural research, outreach, and training).

${ }^{12}$ We thank Marcos Quesada for this observation. 